\title{
Peraclis valdiviae from the Banda Sea (Mollusca, Pteropoda)
}

\author{
S. van der Spoel \\ Institute of Taxonomic Zoology, University of Amsterdam, The Netherlands
}

Keywords: Pteropoda, Peraclis valdiviae, vertical distribution, Banda Sea

\begin{abstract}
The shell of Peraclis valdiviae (Meisenheimer, 1905) from Banda Sea specimens proved to be of a slender Peraclis bispinosa-like type. The specimens showed a very shallow distribution in the Banda Sea due to relatively high deep-water temperatures and vertical mixing.
\end{abstract}

Introduction. - The deep-sea species Peraclis valdiviae (Meisenheimer, 1905) is rarely collected and intact specimens with shells are only reported by Tesch (1948). He was the first to describe the shell, but this description could not be completely accurate as the specimens were rather damaged.

Material from the Snellius II Expedition* collected in the Banda Sea in the period July 1984-March 1985 (Schalk, 1990) provided four specimens with shells. The sample is preserved in alcohol 70\%. In this paper the shell is more fully described. As this bathypelagic snail occurs in a sample of less than $500 \mathrm{~m}$ depth, a typical vertical distribution pattern in the Banda Sea is considered.

Description of the shell. - The measurements of the largest of the four specimens (Figs. $1 \& 2$ ) are: shell height $5 \mathrm{~mm}$, maximum width $4.4 \mathrm{~mm}$, aperture 4.8 $\mathrm{mm}$ in height and $3.6 \mathrm{~mm}$ in width, greatest diameter of the operculum $5.4 \mathrm{~mm}$. When the shell is intact as reconstructed in Fig. 3 its height may be 6 $\mathrm{mm}$. The other three specimens are only slightly smaller. The calcareous shells are opaque white but this is the effect of the preservation that did disappear colour and transparency.

The shell has 3.75 whorls; the body whorl is very large. The spira is rather high, pointing above the body whorl. The calcareous, sinistral shell is covered with a hexagonal calcareous reticulum except for the embryonic, first, whorl and the last half of the body whorl. On the last whorl a thickened rib runs parallel to the suture; in between this thick rib and the suture, transversal rims are found and growth lines are visible.

Growth lines are distinct over the whole shell but most prominent on the body whorl. As can be concluded from the growth lines near the aperture of the shell, a small anterior spine had been present on the aperture, probably supported by the thickened rib. The wavy, spiral ribs around the body whorl, 9 or 10 in number, become stronger near the aperture; the four central ones of these are more prominent than the outer ones. The aperture border is discontinuous, spindle-shaped; a very broad columellar membrane is present forming a spoon-like protrusion at the underside of the aperture supported by the columella.

In an intact specimen a pointed rostrum is sup-

* Research has been carried out as a part of the Snellius II Expedition organized by the Netherlands Council of Sea Research (NRZ) and the Indonesian Institute of Science (LIPI). 


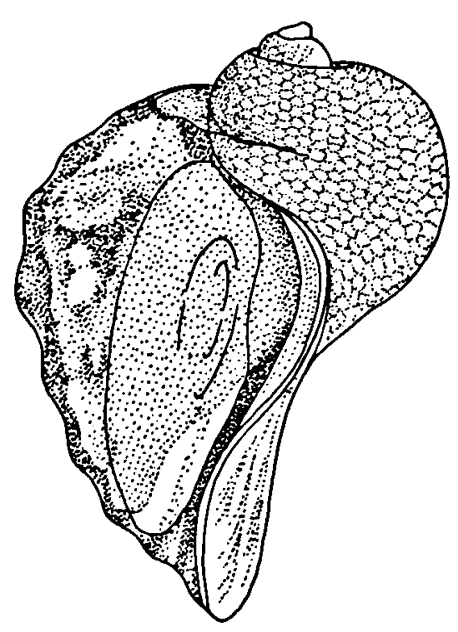

1

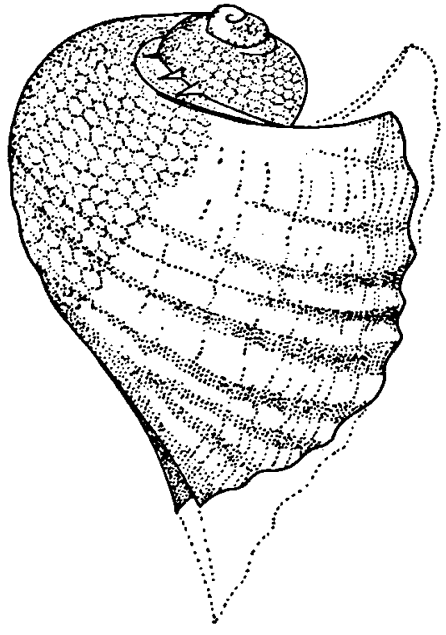

2

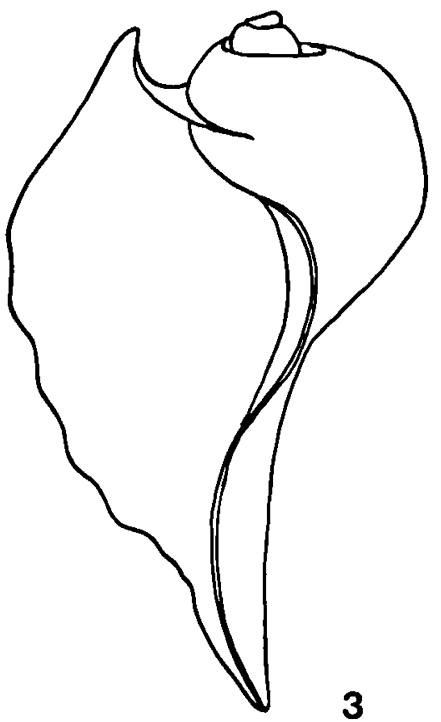

3

Figs. 1-3. Peraclis valdiviae: 1 , shell in apertural view with the soft parts and operculum visible; 2 , shell from dorsal in slightly oblique position, the parts broken of are dotted; 3 , reconstruction of complete shell in apertural view.

posed to be present as illustrated in Fig. 3. The operculum (Fig. 4) with 4.5 whorls is nearly round, very thin and flexible. The first whorls and the last one are coiled in a higher level than the last but one. The typical striation of the operculum, described by Tesch (1948), could not be found in the present specimens; only an irregular reticulated pattern is found in the centre of the whorls.

Discussion. - The illustrations of the shell given by Tesch (1948) gave the impression as if the shell is rather depressed though the spire is high. As can be seen from the illustrations presented here the shell is slender and resembles more that of Peraclis bispinosa Pelseneer, 1888 and that of Procymbulia philiporum Gilmer, 1990. The statement of Tesch that the shell is much more depressed than in for example $P$. bispinosa seems incorrect as the shell is elongate. The shells of both Procymbulia philiporum and Peraclis valdiviae are slender. The spiral ribs on the body whorl characterize $P$. valdiviae from the other species in the genus indeed.

Gilmer (1990) described Procymbulia philiporum as a close relative of Peraclis valdiviae and stated that the genera Peraclis and Procymbulia should be kept separate as the latter is intermediate between the Peraclididae and the Cymbuliidae. All

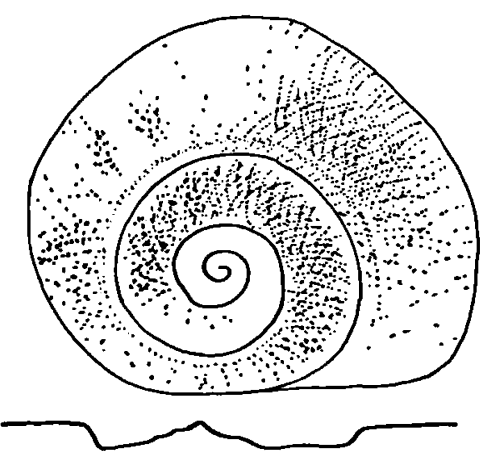

Figs. 4. Peraclis valdiviae: the extremely thin operculum from the outside and in cross-section.

the shell characters that Gilmer (1990) considered to separate Procymbulia from Peraclis can, however, be found also in various Peraclis species. Gilmer (1990) stated "The thin shell could not be removed from the animal ... consequently it dissolved after several weeks in the preservative", so that one can conclude that the shell is described as seen in the tissues and "pseudoconcha" in an aggressive preservative. Therefore the description of shell structure and sculpture are doubtful and seem not sufficient to support the separate status of the genus Procymbulia. As a consequence I propose to retain the generic name Peraclis also for the species 


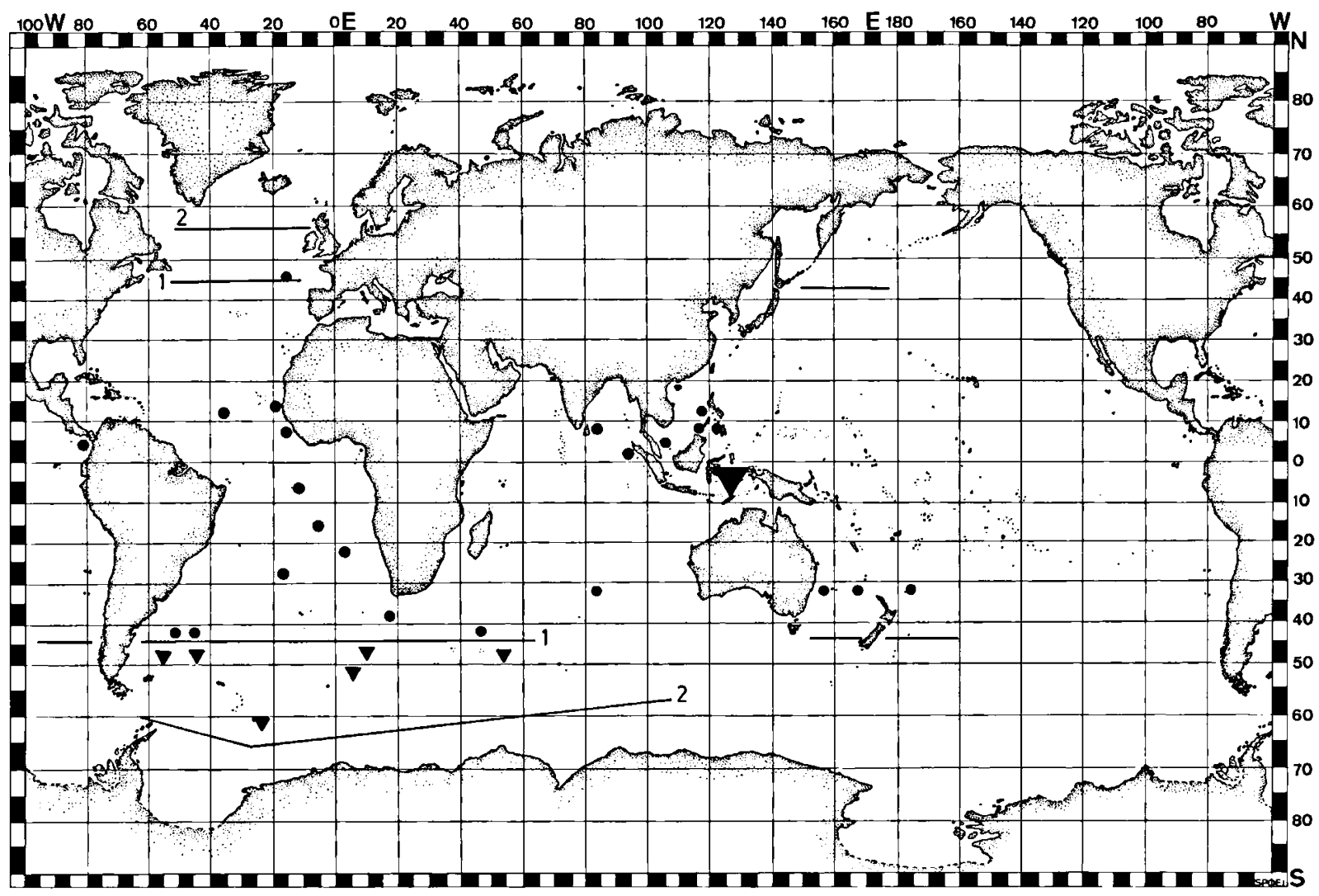

Fig. 5. Distribution of Peraclis valdiviae and related forms: circles = samples from depth below $500 \mathrm{~m}$; triangles $=$ samples from depth shallower than $500 \mathrm{~m}$, large triangle the present material; 1 = supposed border of deep occurrence; $2=$ polarmost border for shallow occurrence.

valdiviae, philiporum, and michaelsarsi (Bonnevie, 1913).

Tesch $(1946,1948)$ described Peraclis valdiviae collected by the Dana Expeditions. In the list of Indo-Pacific specimens published by Tesch (1948) a record of $0-200 \mathrm{~m}$ depth is given but this is a printing error for a sample with $2000 \mathrm{~m}$ wire out. The specimens from the Atlantic described by Tesch (1946) are identified as Procymbulia (= Peraclis) sp. as they could not all be assigned to a species. The specimens were also rather small. It is thus not certain that the specimens collected in the two samples with 300 and $600 \mathrm{~m}$ wire out belong to Peraclis valdiviae. It may be concluded that in the Atlantic, Indian, and Pacific Oceans between $40^{\circ} \mathrm{N}$ and $40^{\circ} \mathrm{S}$ $P$. valdiviae occurs below $2000 \mathrm{~m}$; near $40^{\circ} \mathrm{N}$ and $\mathrm{S}$ the depth of occurrence decreases to 700 or $1000 \mathrm{~m}$.
The Discovery Expedition specimens identified by Massy (1932) are all from Subantarctic and Antarctic waters collected between 0 and $200 \mathrm{~m}$ depth. $P$. valdiviae thus shows a very pronounced subtropical submergence at $40-45^{\circ} \mathrm{N}$ and $40-45^{\circ} \mathrm{S}$.

The Snellius II specimens are collected at 395-500 $\mathrm{m}$ depth in the Banda Sea between 12.18 and $12.58 \mathrm{~h}$ at a water temperature of $9.5-7.9^{\circ} \mathrm{C}$. This is a very shallow sampling depth for this species. In the Banda Sea shallow occurrence of deepsea animals has been reported already by Van der Spoel \& Schalk (1988); among these was the deepsea thecosomatous pteropod Clio andreae Boas, 1886 , reported from $0-102 \mathrm{~m}$ depth. As an explanation for this shallow occurrence the strong and deep vertical mixing and the deviating, higher, temperatures at depth in the Banda Sea were given (Van der Spoel \& Schalk, 1988). It is remarkable that all 
the deep-sea species reported from relatively shallow depths in the Banda Sea are species showing subtropical submergence. $P$. valdiviae confirms this as it shows also strong subtropical submergence.

There are two types of deep-sea species: those primarily adapted to low temperatures at depth (developed recently after the Oligocene when cooling of deep water started) and those adapted to depth only (developed already after the Mid-Cretaceous directly after the rifting of the deep sea in the northern Atlantic) (cf. Van der Spoel et al., 1990). The species with subtropical submergence clearly follow the low temperatures found at depth and more near the surface in polar areas. Probably only these temperature-adapted, and phylogenetically younger species come closer to the surface in the Banda Sea and comparable oceanic areas.

\section{Literature}

Bonnevie, K., 1913 (reprinted 1933). Pteropoda from the "Michael Sars" North Atlantic deep-sea Expedition. Rep. scient. Results Michael Sars N. Atlant. deep Sea Exped., 3(1):
1-69, pls. I-IX.

Gilmer, R.W., 1990. Procymbulia philiporum new species, with a discussion of the genus Procymbulia Meisenheimer, 1905 (Gastropoda: Thecosomata). Nautilus, 104 (4): 11-119.

Massy, A.L., 1932. Mollusca: Gastropoda Thecosomata and Gymnosomata. Discovery Rep., 3: 267-296, pl. XXXIX.

Meisenheimer, J., 1905. Pteropoda. Wiss. Ergebn. dt. TiefseeExped. “Valdivia", 9: [i-iii], i-vi, 1-314, Atlas Pls. I-XXVII, [1-56], maps I-IX.

Pelseneer, P., 1888. Report on the Pteropoda collected by H.M.S. Challenger, during the years $1873-1876,2$. The Thecosomata reports on the scientific results of the voyage of H.M.S. Challenger, during the years 1873-1876. Rep. scient. Results Voy. Challenger, (Zool.) 23 (1): 1-132, pls. I-II.

Schalk, P.H., 1990. Spatial and seasonal variation in pteropods (Mollusca) of Indo-Malayan waters related to watermass distribution. Mar. Biol., 105 (1): 59-71.

Spoel, S. van der, A.C. Pierrot-Bults \& P.H. Schalk, 1990. Probable Mesozoic vicariance in the biogeography of Euphausiacea. Bijdr. Dierk., 60 (3/4): 155-162.

Spoel, S. van der \& P.H. Schalk, 1988. Unique deviations in depth distribution of the deep-sea fauna. Deep-Sea Res., 35 (7A): 1185-1193.

Tesch, J.J., 1946. The thecosomatous pteropods, 1. The Atlantic. Dana Rep., 28: 1-82, pls. I-VIII.

Tesch, J.J., 1948. The thecosomatous pteropods, 2. The IndoPacific. Dana Rep., 30: 1-45, pls. I-III.

Received: 10 March 1992 